\title{
The Differences of Students Learning Outcomes and Metacognitive Skills by Using PBL and Metacognitive-PBL
}

\author{
Syahmani, Dini C. F. Uji Borneo \\ Chemistry Education Study Program, Faculty of Teacher Training Education \\ Universitas Lambung Mangkurat \\ Banjarmasin, Indonesia \\ syahmani0168@gmail.com
}

\begin{abstract}
This study aims to determine the differences of cognitive learning outcome and metacognitive skills between class taught by using PBL and metacognitive-PBL model in salt hydrolysis material. This quasi-experimental research employed the nonequivalent control group design and was conducted at class XI-MIA of SMAN 1 Banjarmasin. The data were collected by using test, questionnaire and interview. They were analyzed using t-test and descriptive analysis. The result of this research showed that there are differences in cognitive learning and metacognitive skills significantly between students who learned by using PBL and metacognitive-PBL model. The students who learned by using metacognitive-PBL model cognitive learning achivement were better than those who learned by using PBL model.
\end{abstract}

Keywords- Cognitive Learning Achievement, MetacognitivePBL Model, Metacognitive Skill, PBL Model, Salt Hydrolysis

\section{INTRODUCTION}

Education is the main capital of a nation in an effort to improve the quality of its human resources. Education should prepare graduates who have high-level thinking skills so that students can solve problems in daily life. High-level thinking skills can be trained with innovative learning to stimulate thinking and learning needs. This can be done in the latest approach that can be used to create a dynamic and active learning environment [1].

The observations and interviews to students and teachers of SMA Negeri 1 Banjarmasin, showed the students just memorized the concepts and did not have good ability to use these concepts when they have problems in real life in relation to the concept of salt hydrolysis. Consequently, the learning achivement achieved by students are beyond the expectations. The learning process should be able to lead the thinking of students so that they will not only remember and understand a variety of data, facts, or concept, but also understand the data, facts, and the concept that can be used as a means to train students' thinking skills in solving problems. According to M. P. Khairuna [2], a person will be successfull in solving the problems, among other things, depends on his awareness of what he has known and how he has done it. This is related to metacognition. Metacognition is a mental activity in cognitive structures that will be done consciously by a person to organize, control and examine the thinking process by himself.

One of the models of learning that can be applied by teachers is PBL or problem-based learning. PBL is a model of learning by getting students to form a knowledge with little guidance or direction of a teacher. PBL helps students to become the selfregulating learners. Teachers continually encourage and reward the students to ask questions and have solutions for real problems, and they will learn to accomplish these tasks autonomously in the rest of their lives [3].

The implementation of the PBL model will make students become actively involved in the learning process. This makes the knowledge becomes more meaningful and makes students easier in understanding it. Thus, the results of the model implementation can improve the student's learning. Problems in PBL will make the students motivated to do metacognitive thinking. By using PBL, the students can give a model of thinking, questioning, criticizing their own ideas and the others' ideas at the same time by exploring new things [4].

Learning process using PBL can make students experience the ambiguity of the problems and be able to find a solution to the difficulties they encountered. This can be overcome by providing questions that guide the students to clarify a problem and help students to solve the problems that they have faced. Through metacognitive questions, the teachers can help the students to be aware of the trending issues and to be able to organize themselves to solve the problems. According to some experts, the metacognitive questions play an important role in making the students' learning process more efficient. For example, questions can help students to: recall their prior-knowledge [5], increase the students' understanding to the task [6], improve their cognitive process [7], use of metacognitive skills [8], improve metacognitive skills [9], and be aware of the problem that they can solve [10].

The study will to determine the differences of cognitive learning outcome and metacognitive skills between class taught by using PBL and metacognitive-PBL model in salt hydrolysis material.

\section{METHODS}

\section{A. Research Design Selecting}

This research used the quasi-experimental method with the nonequivalent control group design and was conducted at class XIMIA of SMAN 1 Banjarmasin Academic year 2014/2015. 


\section{B. Sampling Technique}

The sampling technique used in this research is nonprobability sampling (purposive sampling) [11]. Sample chosen are the XI-MIA1 class as an experimental group and XI-MIA2 class as a control group, each class consists of 36 students.

\section{Instrument and Data Analysis}

The research instruments are tests and non-test. The tests are used for measuring the students' cognitive achievement. The tests are in the essay forms. Validity of instrument is determined by the judgment of six validators. Based on calculations using the equations CVR (Content Validity Ratio), the result is obtained $=1$. This indicates that the instrument of cognitive learning is valid for knowing metacognition skills. The non-tests are questionnaire of metacognition skills and interview guides. The results of validation questionnaire on metacognition skills indicate that any statement on the instrument has the CVR that is equal to 1 , so that the non-test instruments are feasible to be used as the instruments in this research.

The valid instruments are subsequently tested before being used in research to determine the level of reliability. Based on calculations by the Cronbach alpha formula, the obtained value of the degree of cognitive achievement test $=0.481$; metacognition skills test $=0.58$ in the medium category, and the questionnaire on metacognition skills $=$ 0.87 in high category.

Data were analyzed using descriptive and inferential analysis. Inferential analysis used in this research is a t-test. T-test term refers to the test of normality and homogeneity of data. This test aims to determine whether there is a difference is generated between the control group and the experimental group..

\section{RESUlts}

\section{A. Student Learning Achievement}

Students are given a pretest before learning to know their initial cognitive learning achievement. After learning process ends, the students are given a posttest to determine their cognitive learning achievements. Data of pretest and posttest of cognitive learning achievements can be seen in Table 1 .

TABLE I. PRETEST AND POSTTEST RESULTS OF STUDENTS' LEARNING ACHIEVEMENT

\begin{tabular}{|c|c|c|c|c|c|}
\hline $\begin{array}{c}\text { Learning } \\
\text { Result } \\
(\%)\end{array}$ & \multirow{2}{*}{ Category } & \multicolumn{2}{c|}{$\begin{array}{c}\text { Frequency } \\
\text { Experiment } \\
\text { Class }\end{array}$} & \multicolumn{2}{c|}{$\begin{array}{c}\text { Frequency } \\
\text { Control Class }\end{array}$} \\
\cline { 3 - 6 } & & Pretest & Posttest & Pretest & Posttest \\
\hline 100 & Special & 0 & 0 & 0 & 0 \\
\hline $76-99$ & Very good & 0 & 10 & 0 & 1 \\
\hline $60-75$ & Good & 1 & 7 & 0 & 7 \\
\hline$<60$ & Less & 35 & 19 & 36 & 28 \\
\hline \multicolumn{2}{|c|}{ Total } & 36 & 36 & 36 & 36 \\
\hline
\end{tabular}

Based on the data in Table 1 above, we can calculate the average value of a class that can be seen in Table 2 below.

TABLE II. AVERAGE VALUE OF STUDENTS' LEARNING ACHIEVEMENT

\begin{tabular}{|c|c|c|c|c|}
\hline \multirow{2}{*}{ Value } & \multicolumn{2}{|c|}{ Experiment Class } & \multicolumn{2}{c|}{$\begin{array}{c}\text { Control } \\
\text { Class }\end{array}$} \\
\cline { 2 - 5 } & Pretest & Posttest & Pretest & Posttest \\
\hline Lowest & 0 & 10 & 0 & 0 \\
\hline Highest & 70 & 90 & 50 & 80 \\
\hline Average & 25,55 & 53,88 & 19,16 & 42,22 \\
\hline
\end{tabular}

Data of cognitive learning results of the two subsequent classes are categorized based on the applicable standard of completeness. The data from Standard of Minimum Learning Mastery) (SKBM) can be seen in Table 3.

TABLE III. STANDARD MASTERY OF LEARNING

\begin{tabular}{|c|c|c|c|}
\hline Value & $\begin{array}{c}\text { Experiment } \\
\text { Class }\end{array}$ & $\begin{array}{c}\text { Control } \\
\text { Class }\end{array}$ & Information \\
\hline$<80$ & 26 & 35 & Not Complete \\
\hline$\geq 80$ & 10 & 1 & Completed \\
\hline
\end{tabular}

Data of cognitive achievement obtained from the pretest and posttest data is then processed into $\mathrm{N}$-gain to determine the extent to students in each class that have increased cognitive achievement after participating in the learning on the salt hydrolysis material. The average $\mathrm{N}$-gain obtained and interpreted in accordance with the criteria proposed by Hake [12] as shown in Table 4 below.

TABLE IV. INTERPRETATION OF N-GAIN STUDENTS LEARNING ACHIEVEMENT

\begin{tabular}{|c|c|c|}
\hline Class & Average N-gain & Category \\
\hline Experiment & 0,40 & Moderate \\
\hline Control & 0,29 & Weak \\
\hline
\end{tabular}

Based on the calculation of normality and homogeneity test of pretest and posttest data, the data of students learning achievement was normal and homogen. So, analyze of the hypothesis can use ttest.

The t-test was used to determine the difference of students' learning achievements between experiment class and control class. The t-test result can be seen in Table 5 .

TABLE V. THE RESULTS OF T-TEST OF STUDENTS COGNITIVE LEARNING

\begin{tabular}{|c|c|c|c|c|c|c|c|}
\hline Class & $\mathbf{N}$ & $\mathbf{D b}$ & $\overline{\mathbf{x}}$ & $\mathbf{S}$ & $\begin{array}{c}\mathbf{t}- \\
\text { count }\end{array}$ & $\begin{array}{c}\mathbf{t}- \\
\text { table }\end{array}$ & Information \\
\cline { 1 - 5 } Experiment & 36 & 35 & 53,88 & 524,72 & 2,29 & 2 & $\begin{array}{c}\mathrm{H}_{0} \text { rejected } \\
\text { There is } \\
\text { significant } \\
\text { difference }\end{array}$ \\
\hline Control & 36 & 35 & 42,22 & 378,58 & & & \\
\hline
\end{tabular}

\section{B. Metacognition Skills of Students}

TABLE VI. DATA FROM STUDENTS' METACOGNITION SKILLS GAINED FROM THE PRETEST AND POSTTEST CAN BE SEEN IN TABLE 6.

\section{STUDENTS' METACOGNITION SKILLS}

\begin{tabular}{|c|l|c|c|c|c|}
\hline \multirow{2}{*}{$\begin{array}{c}\text { Value } \\
\text { Inter- } \\
\text { val }\end{array}$} & \multirow{2}{*}{ Category } & \multicolumn{2}{c|}{$\begin{array}{c}\text { Frequency } \\
\text { Experiment } \\
\text { Class }\end{array}$} & \multicolumn{2}{c|}{$\begin{array}{c}\text { Frequency } \\
\text { Control } \\
\text { Class }\end{array}$} \\
\cline { 3 - 6 } & & $\begin{array}{c}\text { Pret } \\
\text { est }\end{array}$ & $\begin{array}{c}\text { Postte } \\
\text { st }\end{array}$ & $\begin{array}{c}\text { Pret } \\
\text { est }\end{array}$ & $\begin{array}{c}\text { Posttes } \\
\text { t }\end{array}$ \\
\hline $0-20$ & Undeveloped & 17 & 0 & 12 & 0 \\
\hline $21-40$ & Still very risky & 17 & 8 & 22 & 15 \\
\hline $41-60$ & Began to grow & 2 & 18 & 2 & 13 \\
\hline $61-80$ & $\begin{array}{l}\text { Already well } \\
\text { developed }\end{array}$ & 0 & 10 & 0 & 8 \\
\hline $81-100$ & Developing very well & 0 & 0 & 0 & 0 \\
\hline
\end{tabular}

Based on data from Table 10, we can calculate the average value of a class that can be seen in Table 7. 
TABLE VII. AVERAGE VALUE PRETEST AND POSTTEST IN METACOGNITION SKILLS

\begin{tabular}{|c|c|c|c|c|}
\hline \multirow{2}{*}{ Value } & \multicolumn{2}{|c|}{ Experiment Class } & \multicolumn{2}{c|}{ Control Class } \\
\cline { 2 - 5 } & Pretest & Posttest & Pretest & Posttest \\
\hline Lowest & 0 & 29,16 & 0 & 24,99 \\
\hline Highest & 45,83 & 79,16 & 41,66 & 79,16 \\
\hline Average & 21,05 & 53,34 & 21,98 & 43,96 \\
\hline
\end{tabular}

Overall, the percentage of posttest classification at each indicator metacognition skills experimental class and a control class contained in Fig 1.

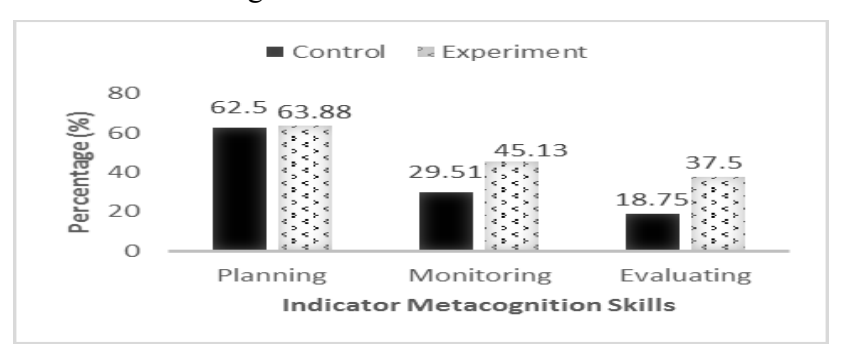

Fig 1 Percentage of the average results of the written test on every indicator of students' metacognition skills of experimental class and control class

Data of metacognition skills test obtained from the pretest and posttest data are then processed into N-gain to determine the extent to which students in each class increase metacognition skills after participating in the learning process on the material of salt hydrolysis. Average N-gain can be shown in Table 8 .

TABLE VIII. INTERPRETATION N-GAIN STUDENTS' METACOGNITION SKILLS

\begin{tabular}{|c|c|c|}
\hline Class & $\begin{array}{c}\text { Average N- } \\
\text { gain }\end{array}$ & Category \\
\hline Experiment & 0,40 & Moderate \\
\hline Control & 0,27 & Weak \\
\hline
\end{tabular}

The statistical test of homogeneity and normality of pretest and posttest 0n metacognition skills data show that the data of pretest and posttest on metacognition skills are normally distributed and homogeneous or similar. So, the further analysis can be done by using t-test.

The results of the t-test of students' metacognition skills in the experimental and the control can be seen in Table 9 .

TABLE IX. THE RESULTS OF T-TEST OF STUDENTS METACOGNITION SKILLS

\begin{tabular}{|c|c|c|c|c|c|c|c|}
\hline Class & $\mathbf{N}$ & $\mathbf{D b}$ & $\overline{\mathbf{x}}$ & $\mathbf{S}$ & $\begin{array}{c}\mathbf{t}- \\
\text { count }\end{array}$ & $\begin{array}{c}\mathbf{t}- \\
\text { table }\end{array}$ & Information \\
\hline Experiment & 36 & 35 & 53,34 & 155,16 & 2,72 & 2 & $\begin{array}{c}\text { H0 rejected } \\
\text { There is } \\
\text { significant } \\
\text { difference }\end{array}$ \\
\hline Control & 36 & 35 & 43,96 & 261,47 & & & \\
\hline
\end{tabular}

\section{Questionnaire of Metacognition Skills}

Data Results of the questionnaire of students' metacognition skills acquired from pretest and posttest can be seen in Table 10.
TABLE X. LIST OF THE PRETEST AND POSTTEST QUESTIONNAIRE OF STUDENTS' METACOGNITION SKILLS

\begin{tabular}{|c|c|c|c|c|c|}
\hline \multirow{2}{*}{$\begin{array}{c}\text { Value } \\
\text { Inter- } \\
\text { val }\end{array}$} & \multirow{2}{*}{ Category } & \multicolumn{2}{c|}{$\begin{array}{c}\text { Frequency } \\
\text { Experiment } \\
\text { Class }\end{array}$} & \multicolumn{2}{c|}{$\begin{array}{c}\text { Frequency } \\
\text { Control } \\
\text { Class }\end{array}$} \\
\cline { 3 - 6 } & & $\begin{array}{c}\text { Pretes } \\
\text { t }\end{array}$ & $\begin{array}{c}\text { Postte } \\
\text { st }\end{array}$ & $\begin{array}{c}\text { Pret } \\
\text { est }\end{array}$ & $\begin{array}{c}\text { Posttes } \\
\text { t }\end{array}$ \\
\hline $0-20$ & Undeveloped & 0 & 0 & 0 & 0 \\
\hline $21-40$ & Still very risky & 0 & 0 & 0 & 0 \\
\hline $41-60$ & Began to grow & 8 & 4 & 5 & 3 \\
\hline $61-80$ & $\begin{array}{c}\text { Already well } \\
\text { developed }\end{array}$ & 25 & 25 & 29 & 30 \\
\hline $81-100$ & $\begin{array}{c}\text { Developing very } \\
\text { well }\end{array}$ & 3 & 7 & 2 & 3 \\
\hline
\end{tabular}

Based on data from Table 16 above, we can calculate the average value of a class that can be seen in Table 11 .

TABLE XI. AVERAGE VALUE OF PRETEST AND POSTTEST QUESTIONNAIRE OF METACOGNITION SKILL

\begin{tabular}{|c|c|c|c|c|}
\hline \multirow{2}{*}{ Value } & \multicolumn{2}{|c|}{ Experiment Class } & \multicolumn{2}{c|}{ Control Class } \\
\cline { 2 - 5 } & Pretest & Posttest & Pretest & Posttest \\
\hline Lowest & 50 & 54 & 49 & 53 \\
\hline Highest & 93 & 93 & 86 & 92 \\
\hline Average & 67,4 & 72,4 & 68,02 & 70,0 \\
\hline
\end{tabular}

Overall, the percentage of posttest classification at each indicator of metacognition skills of experimental classes and control classes are in Fig 2.

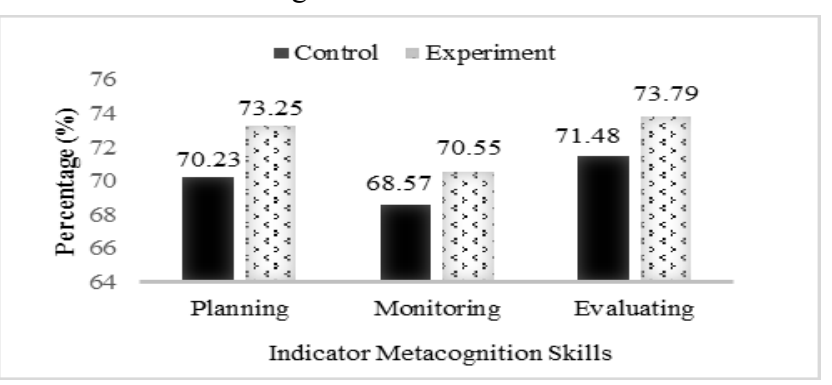

Fig 2 Percentage of questionnaire result in each indicator of students' metacognition skills of experiment class and control class

\section{The Average Value of Skills Metacognition}

The average value of each indicator metacognition skills can be seen from the results of written tests, and questionnaires of metacognition skills can be seen in Fig 3 .

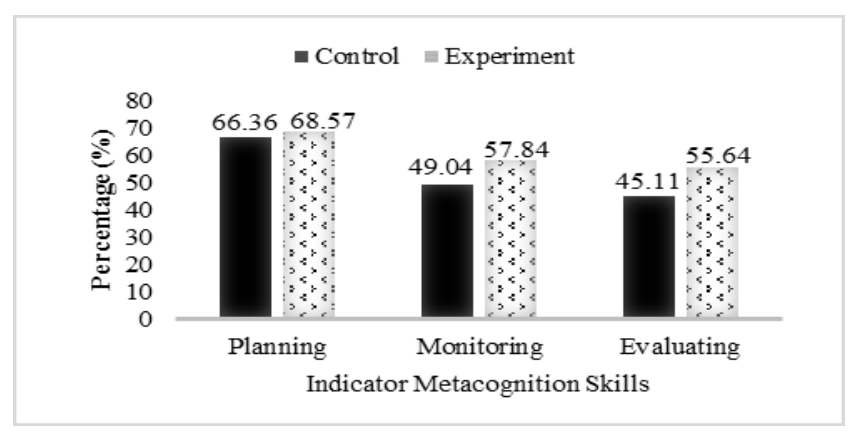

Fig 3 Percentage of questionnaire result in each indicator of students' metacognition skill of experiment class and control class 


\section{DISCUSSION}

\section{A. Student Learning Achivement}

Cognitive achievement tests are performed twice: before learning (pretest) and after learning (posttest). Based on the results of the homogeneity test, pretest results of students in the experimental class and control indicates as homogeneous. In addition, based on the results of inferential analysis using t-test on the pretest, students in both classes have no significant difference in cognitive achievements between experimental and control class students.

Based on the test results of inferential analysis using t-test, it can be said that there is a significant difference on the result between these two classes after being given the treatment. The difference is due to the learning achievement of the experimental class using metacognitive-PBL model, and learning achievement in class control using PBL model. Metacognitive-PBL model is able to create a conducive atmosphere of learning. This is because the students are more active, more likely to be enthusiastic in accomplishing the given tasks, and of course it will affect their learning achievements.

Comparison of improvement of students' cognitive learning achievements in the experimental class and control one can be known by determining the value of $\mathrm{N}$-gain in both classes of the pretest and posttest for each class. The research showed the average value of the two classes of N-gain, then they are compared to determine which class whose cognitive learning achievement is better. The average of $\mathrm{N}$-gain of experimental class is 0.40 and it is included in the medium category, while the average of $\mathrm{N}$-gain of the control class is 0.29 and it is included in the weak category.It can be said that the metacognitive-PBL model is more effective in improving the students' cognitive learning achievements in this research.

\section{B. Metacognition Skills}

Metacognition skills tests are performed twice: before learning (pretest) and after learning (posttest). All the students in the experimental and the control classes still have the very risky metacognition skills. It can be said that the students in both classes have equal metacognition skills. This is in line with the results of $t$ test which is performed on the data of pretest results showing that there is no difference in the test of metacognition skills in the experimental class students from that of the grade control ones. Based on the inferential analysis using t-test on the posttest data from experimental and control class students, it is known that there is a significant difference in the test results.

The difference of metacognition skills results between two classes are because the experimental class was taught using the metacognitive-PBL model while the control class was taught using the model of PBL. In the PBL model, the teaching process still encounters obstacles such as: there are still many students who are difficult to understand the problem, they are still difficult to express ideas openly and freely, they are difficult to formulate hypotheses and determine the solution of the problem [10]. The use of metacognitive questioning helps students realize that the troubleshooting process can set their own progress in solving the problem. So, learning by using metacognitive-PBL model will facilitate students in solving problems. In addition, students will be encouraged to think and get more focused in solving problems so that metacognition skills will be more developed.

Implementation of learning in the experiment class by using metacognitive-PBL model is done by giving a problem to students in the form of student's worksheet (LKS). Each metacognitive-PBL model activity is linked to the students' metacognition skills so that there is a difference in posttest performance between the two classes of the samples of research. The first stage in the metacognitive-PBL model can directed to the students to solve the problem. Students are expected to understand the problem that are presented in an authentic discourse and answer comprehension questions. Indicator of metacognition skills in this first stage is planning.

The second stage is to prepare the students to learn. The ability to be expected at this stage is that they begin to gather and discuss with each group and are asked to answer the question. Indicators in this second phase are still related to planning skills.

The third stage is to assist independent and group research. At this stage, the students are expected to be able to carry out an investigation to find solutions to the problems that they have faced and the students are also asked to answer strategic questions and reflective questions (skills related to monitoring). Indicators of metacognition skills in this third stage is monitoring. After investigating, the students are expected to check back on their results.

The fourth stage is developing and presenting the artifacts and a displayed objects. The students are expected to present the results of their discussion in front of the class and answer comprehension questions, which is related to the intent of the problem and understand the answers of reflective questions (skills related to monitoring) in order to check the submitted answers.

The fifth stage is to analyze and evaluate the problem-solving process. The students are expected to see the steps that are used from the beginning to the end in solving the problem, whether it is appropriate or there are still shortcomings (not optimal) by answering the questions (skills related to evaluation). Indicators of metacognition skills that illustrates this is the evaluation.

Students are required to solve the problem by answering questions related to metacognition skills such as planning, monitoring and evaluation. Students in high category have been able to explain the problem. They write data to know how to overcome the problem. Data written are complete and correct. Higher level students have been able to explore their knowledge to solve the problems, because they are already skilled in the use of planning skills for those who have understood the content of the questions well. They explore their mind to recall their background knowledge that will help them to complete the task, and they know what to be done first to complete the task [13].

Students have a good knowledge so that they can solve problems by applying the good strategy. This is in relation to [2] that a person's success in solving the problem depends on his awareness of what he has known. However, on questions, related to the monitoring skills when students are asked to check the results obtained, they have not been able to reveal the reasons why the strategy adopted is right or not. According to [14], the students have limited ability to express ideas or thoughts, but they may also be able to explain ideas in a different way, so they only give reasons as what comes from mind.

Questions related to the evaluation skills ask the students to see whether the measurement from beginning to end have been appropriate as it was previously planned. However, in answering the questions, the reasons are linked with strategies implemented using a planned strategy to resolve the problems.

High category students have not been able to answer questions related to the evaluation skills well because they are not familiar to answer the questions on evaluation skills as the test item. They are still not trained optimally and only have a small quantity in the learning process. Questions pertaining to the evaluation skills need to be trained regularly to develop their evaluation skills. The students who are included in the category of metacognitive skills are already well developed.

The students in moderate category answering the questions related the planning skills on the first question indicate that they are able to reveal problems in the right ways. The written data are also appropriate. But they do not have a good ability to determine a strategy to solve the problem as expected. They are only able to 
write a general strategy in which they do not mention the details of the steps that will be used to solve the problems. This is because they have difficulties in revealing a strategy or a plan for solving the problem. This is in line with [15] that the respondents find it difficult to make a planning to solve the problems.

Furthermore, based on the students' answers to questions related to planning skills, in other questions the students have been able to mention the application of these questions, but the their answers are incomplete. Then when they are asked to identify the data, they are able to mention them, but there are mistakes in writing the chemical formula for the compound. They do not mention in detail what steps that should be done in solving the problems. This is because they have never encountered such problems. According to Polya, at the stage of thinking of a plan, the student must be able to think about what steps are important and support each other in order to solve their problems. He also says that the ability to think in right way can only be done if the students have previously equipped with the adequate knowledge in the sense of the issues that they have faced, not new at all but a kind of approach [16].

Students are trained in monitoring or examining the results of problem solving so that they are less precise in the disclosure of the reasons of why the answers given are appropriate. They do not have the skills of a good monitoring in solving this problem because they do not determine and understand the right strategy to solve the problem. They need to monitor their understanding of the main ideas. However, the monitor is not appropriate if they do not understand what the main idea is or how to find it [17]. They are not accustomed to and trained in skills of evaluation. They are not able to give exact answers as expected. They do not disclose the reasons for linking the strategy adopted by the strategy that has been previously planned. Thet also provide answers to the other questions through the strategy that has been applied in accordance with the planned strategy, but they do not mention in detail of the strategy that will be done in solving the problem. The strategy adopted is not proper to assess the students' answers on the skills of evaluation. They are included in the category of metacognition skills for starting to develop.

Low category students' answers to questions related to planning skills on the first question shows that students are able to reveal problems with the right, the data is also right, but the strategies was mentioned to solve the problem was considered inappropriate because it is still very general. Students have not been able to write a problem solving strategy as expected due to the low level of students who do not know what they needs to be written in making the settlement plan.

The students' answers to questions related to planning skills in other questions showed that the students have not skilled in the use of good planning skills when they asked to explain problem, they said the data that was known the matter and when they asked to determine the strategy in solving the problem. This caused the students do not understand the problem fully. Student is said to understand the problem if students are capable to understand and asked the answers of the given problem [18]. Based on these opinions, it is normal that students have not been able to reveal the appropriate strategies to solve problems because the students themselves do not understand the problem well.

Students feel that they have answers in right way, but truly, it is not appropriate because the students still do not understand or less mastered with the material that being tested. Refer to [19], which stated due to lack of mastery of the concept of prior knowledge, the students did not realize that they did not know. It appears that the self-efficacy or students' own estimates about themselves less. Students did not have the right strategy to solve the problem so it can be said that the students have not been trained in the use of monitoring skills. One reason is that students have not been able to make plans that define the right strategy in solving the problem. There is a strong relationship between the success of solving problems with a person's ability to monitor the process of thinking [20].

According to the students, the strategy that has been applied in accordance with the planned strategy is appropriate, but students do not mention the detail of the strategy that will be done in solving the problem, but the strategy that was adopted was not proper. Students have not been trained in the use of skills evaluation. Furthermore, the other students did not answer questions related to the evaluation skills. Students are not skilled in the use of planning skills and also monitoring properly. The skills of planning, monitoring and evaluation are related to each other in solving problems. So, three components of metacognition, which are planning, monitoring and evaluation as a series of interrelated in metacognitive activities [21]. Students in low category of metacognition skills are still very risky.

Overall, interviews showed that students from the lower class and middle-class is still less skilled in the use of metacognition skills of planning, monitoring and evaluation in problem solving, so the skill category metacognition is still very risky for students of lower class and began to develop for middle grade students. Basic knowledge of the material that being tested is also an important factor in the use of components of students' metacognition skills. Lack of knowledge of students about the material that being tested will impact the students but also decision to solve the problem.

The success of metacognition skills in the experiment class can only be seen by the results of the written test, but can also based on the results of questionnaires metacognition skills. The average results of the questionnaire showed that the experiment class and control class are equal in the category and already well developed, but the average value of the experiment class is higher at 72.47, while the control class is 70.02. This happens because the metacognitive- $P B L$ model is applied to the experiment class that had a positive impact on learning, including the metacognition skills of students. The results are consistent with the results of research according to [10], that the granting of questions of metacognitive gave a positive impact on learning, among others, (1) make students more cautious in making decisions, (2) make students more courageous in expressing opinions, (3) make students more passion for achieving results better, and (4) raises the curiosity of students. Learning that utilizes metacognitive question is able to create an atmosphere conducive to learning. This is because students are more active, more likely to survive in the given tasks.

The results of the written test in experiment class and control class indicates that the indicator of metacognition skills achieved by the student with the highest percentage, medium, and lowest in succession are the skills of planning, monitoring and evaluation. This is in contrast to the results of the questionnaire metacognition skills, where skills indicators achieved by the student with the highest percentage, medium, 
and lowest in a row is a skill evaluation, planning and monitoring.

The big differences of sequence metacognition skills student achievement indicators caused when filling questionnaires disadvantaged students to assess themselves. Students having difficulty in conducting self-assessment of what they have done to resolve the problems contained in the problem so that in filling out the questionnaire used as an instrument of self-assessment showed that students have a good self-assessment against the use metacognition skills in solving problems. This resulted in the achievement indicator of metacognition skills based on questionnaire results that are not in line with the results of the written test. Refer to [22] that people generally choose the option that they think is reasonable and is the optimal choice in the self-assessment, so that there is a failure to recognize that a person has the skills or abilities are weak and will produce the opinion that a person has the skills or abilities are good.

The result of the calculation of the average of each indicator skill of students' metacognition in experiment class and control class can be seen by the results of the written test and the results of the questionnaire skills of metacognition that indicates the skills of the students in planning is the monitoring. While the lowest percentage achieved by the students is the skill of evaluation. The results of this study are consistent according to Dignath et al. [23], based on the results of investigating studies, the effect of self-regulation training on learning and strategy used among the students in grade 6 indicates that the metacognitive strategy training in planning and monitoring are more successful than metacognitive strategies in the planning and evaluation. The average result shows that the metacognitive strategy training in the planning and monitoring is 1.50 , while the average result of the training of metacognitive strategies in the planning and evaluation is 1.46 .

\section{Relationship Between Metacognition and Cognitive Learning}

Metacognitive skills are believed to have an influence on the students' cognitive learning outcomes. It can be seen that the higher class students having the metacognitive skills have already well developed (score of 79.16). Seen from the cognitive learning, they are in a very good /optimal level (score of 90) and have reached SKBM (minimum standard of learning mastery). It can also be seen from the lower class students. The lower class students who have metacognitive skills are still highly at risk (score 37.49 ), when the cognitive learning is at a low level (score of 10) and have not reached SKBM. The students with high metacognitive skills, also have high learning achievement and so on.

According to [24] metacognition especially has an important role in improving the ability to learn and solve problems. There is a very close relationship between learning outcomes and metacognitive skills, and both are an integral unit. Efforts to improve the person's cognitive abilities should be supported by increasing metacognitive skills, and vice versa. In implementing the problem-solving activities, cognitive and metacognitive processes can take place in tandem, and mutually support each other.
Middle class students have started to develop metacognitive skills (score 58.33). Seen from the cognitive learning, they are in a very good/optimal level (score of 80 ) and has reached SKBM. Based on the result, it seems that the cognitive learning achievement is better than that of metacognitive skills. That is because the students have not been trained in the use of metacognitive skills when solving problems. The metacognitive development is not an automatic process, but is the result of a lengthy development process of the cognitive system [25].

Based on observations and discussion, the findings obtained are:

(1) Metacognitive-PBL model can facilitate the students' learning to develop skills such as metacognitive skills of planning, monitoring and evaluating to facilitate students in solving problems.

(2) Students can establish the facts and concepts through the provision of supported problems with questions guiding the students to clarify a problem and resolve the issue so that they do not only develop their cognitive abilities but also develop their metacognitive skills

\section{CONCLUSIONS AND RECOMMENDATIONS}

Based on the results of research and discussion, we can conclude that: (1) there are significant difference in cognitive learning outcomes between the students who learn the material of salt hydrolysis using metacognitive-PBL models and those who learn the material of salt hydrolysis using PBL models, and (2) there are significant difference in cognitive learning outcomes between students who learn the material of salt hydrolysis using metacognitive-PBL models and those who learn the material of salt hydrolysis using PBL models.

The suggestions are: (1) the teachers of chemistry can consider to implement a metacognitive-PBL model to improve learning outcomes and students' metacognitive skills of, (2) teachers and others who will use the metacognitive-PBL model in the learning activities, should set the time precisely because this model requires more time, (3) the teachers should provide more guidance to students when giving a training of metacognitive skills in the learning process of metacognitive skills so that the students can develop better.

\section{REFERENCES}

[1] T. Barrett \& S. Moore, New Approaches to Problem-based Learning Revitalising Your Practice in Higher Education. Routledge, New York and London, 2011.

[2] M. P. Khairuna, Penerapan Pendekatan Metakognisi untuk Meningkat-kan Kemampuan Siswa Kelas $V$ SD dalam Memodelkan Soal Cerita Matematika pada Pokok Bahasan Pecahan. Tesis Magister. Program Pascasarjana UNIMED, Medan, 2010. (Unpublished).

[3] R. I. Arends, Belajar untuk Mengajar. Edisi ke-9, Jakarta, 2013.

[4] T. Amir, Inovasi Pendidikan Melalui Problem Based Learning. Prenada Media Group, Jakarta, 2009.

[5] M. E. Osman \& M.J. Hannafin, Effects of advance questioning and prior knowledge on science learning. Journal of Educational Research, 88 (1), 5-14, 1994. 
[6] B. Kramarski \& O. Zeichner, Using technology to enhance mathematical reasoning: Effects of feedback and self-regulation learning. Educational Media International, 38, 77-83, 2001.

[7] Z. Kaberman \& Y. J. Dori, Metacognition in chemical education: Question posing in the case-based computerized learning environment. Instructional Science, 37, 403-436. 2009.

[8] L.N. Conner, Cueing metacognition to improve researching and essay writing in a final year high school biology class. Research in Science Education, 37 (1), 1-16. 2007.

[9] L.K.,Taylor, S.R. Alber, \& D.W. Walker, The comparative effects of a modified self-questioning strategy and story mapping on the reading comprehension of elementary students with learning disabilities. Journal of Behavioral Education, 11 (2), 69-87, 2002.

[10] E. D. Krisna, I. G. P. Sudiarta, \& G. Suweken, Pengaruh model pembelajaran berbasis masalah berbantuan pertanyaan metakognitif terhadap prestasi belajar matematika siswa ditinjau dari motivasi berprestasi. e-Journal Program Pascasarjana Universitas Pendidikan Ganesha Progran Studi Matematika. Vol. 2, 2013, pp 1-11.

[11] Sugiyono, Metode Penelitian Pendidikan: Pendekatan Kuantitatif, Kualitatif, dan R\&D. Alfabeta, Bandung, 2013.

[12] Hake, R. R, Analyzing Change Gain Scores. Accessed on http://www.physics.indiana.edu/ sdi/AnalyzingChange-Gain.pdf. December 1999.

[13] F. Aprilia \& B. Sugiarto. 2013. Keterampilan metakognitif siswa melalui penerapan model pembelajaran inkuiri terbimbing pada materi hidrolisis garam. Unesa Journal of Chemical Education. Vol. 2 No. 332013 pp.36-41.

[14] T. Sinurat, Pemanfaatan Model Open-Ended untuk Peningkatan Kemampuan Berbicara Informatif. Research Report. Universitas Negeri Medan, Medan. 2013.

[15] Ninik, Hobri dan Suharto, Analisis kemampuan pemecahan masalah untuk setiap tahap model polya dari siswa SMK Ibu Pakusari jurusan
Multimedia pada pokok bahasan Program Linier. Kadikma. Vol. 5. No. 3 Desember 2014, pp 61-68.

[16] D. P. Utomo, Pembelajaran Lingkaran dengan Pendekatan Pemecahan Masalah Versi Polya pada Kelas VIII di SMP PGRI 01 $D A U$. Research Report. Universitas Muhammadiyah Malang, 2012.

[17] W. M. Utami, Teori Metakognisi dan Problem Solving. Accessed on http://wahyumurtiutami.wordpress.com. tanggal 2 Desember 2011.

[18] Ifanali, Penerapan Langkah-langkah Polya untuk meningkatkan kemampuan pemecahan masalah soal cerita pecahan pada siswa kelas VII SMP Negeri 13 Palu. Jurnal Elektronik Pendidikan Matematika Tadulako. Vol. 01. No. 03 Maret 2014, pp 147-158.

[19] K. Nugrahaningsih, Metakognisi siswa SMA kelas akselerasi dalam menyelesaikan $\mathrm{m}$ asalah $\mathrm{m}$ atematika. Magistra. No. 82 Desember 2012, pp 37-50.

[20] S.W. Danoebroto, Meningkatkan kemampuan pemecahan masalah melalui pendekatan PMRI dan pelatihan metakognitif. Jurnal Penelitian dan Evaluasi Pendidikan. No. 1, Tahun XI, 2008.

[21] G. Iswahyudi, Metakognisi Mahasiswa dalam Memecahkan Masalah Pembuktian Berdasarkan Langkah-langkah Polya. Research Report. Unes. 2010

[22] J. Metcalfe, Cognitive optimism: self deception or memory-based processing heuristics?. Personality and Social Psychology Review, Lawrence Erlbaum Associate, Inc. Vol. 2, No. 2. 1998. pp 100-110.

[23] E. R. Lai, Metacognition: A Literature Review. Accessed on http://images.pearsonassessments.com/images/tmrs/ Metacognition_Literature_Review-Final.pdf. tanggal 20 Oktober 2011..

[24] M.Anggo, Pelibatan Metakognisi dalam pemecahan masalah matematika. Edumatica. Vol. 1, Nomor 01 April 2011, 1-8.

[25] Panaoura, A \& G. Philippou. 2001. Young Pupils' Metacognitive Abilities in Mathematics in Relation to Working Memory and Processing Efficiency. Accessed on http://www.researchgate.net.at 23 Desember 2014 